FACTA UNIVERSITATIS

Series: Economics and Organization Vol. 18, No 1 , 2021, pp. 89 - 102

https://doi.org/10.22190/FUEO201130007P

Original Scientific Paper

\title{
THE IMPORTANCE OF MARKETING COMMUNICATION FOR ATTRACTING AND RETAINING INSURANCE SERVICE USERS
}

\author{
UDC 658.8 \\ 368
}

\begin{abstract}
Slavica Popović, Mira Avramović
Academy of Vocational Studies Southern Serbia, Department of Business Studies, Leskovac, Serbia
\end{abstract}

\begin{abstract}
The assumption of successful marketing communication within the service sector is the establishment of two-way interactive communication between service users and service companies. The aim of the strategy of marketing communication is attracting new users, but also retaining the existing users of services and establishing long-term relations with them. A successful achievement of the aim of marketing communication requires that the marketing message is created according to the characteristics and preferences of the target audience. The role of marketing communication differs depending on the stage of the selling process. During the pre-purchase stage, the aim of marketing communication is to inform potential users so that they could create preferences towards the company's offer. By applying the adequate forms of marketing communication during the stage of using the service, the company tends to explain to and introduce users to the process of servicing and to provide support in solving the occurring problems. The confirmation of users' positive impressions and the resolution of possible problems which can occur during the process of service provision represent the aim of marketing communication during the post-purchase stage.
\end{abstract}

Key words: marketing communication, service user, attracting, satisfaction, retaining service users

JEL Classification: M31, M37

Received November 30, 2020 / Revised December 12, 2020 / Accepted December 14, 2020

Corresponding author: Slavica Popović

Academy of Vocational Studies Southern Serbia, Department of Business Studies, Leskovac, Serbia

E-mail: popovic.slavica@ hotmail.com 


\section{INTRODUCTION}

The marketing concept in insurance companies implies a complete orientation towards meeting the needs of insurance service users. Through the process of defining and implementing the research programme, the insurance company identifies the needs, desires and demands of service users. On the basis of research results, it creates an adequate offer. By selecting the form, marketing communication informs and creates the awareness of potential users about the offer, and stimulates interest and demand. The offer of insurance companies is standardised and the possible diversification is minimal. Therefore, the achievement of competitive advantage of insurance companies is based on the achievement of satisfaction and, thus, retaining insurance service users.

The strategy of marketing communication originates from the company's marketing strategy. Depending on the goals set by the company, the priorities and goals of the strategy of marketing communication are defined. The effective and efficient strategy of marketing communication is a prerequisite for business success of insurance companies. If that defined goal of the insurance company is to attract and retain service users, then the role of marketing communication is different in every stage of the purchase process. A logical time order of activities is the creation and announcement of realistic promises, fulfilment of the given promises and the establishment of communication after the completion of the purchase process. A successful implementation of a defined goal requires that the insurance company continually monitors the changes in the users' needs and demands and that it achieves an intense communication with users during the provision of services, as well as with those users who have stopped cooperating with the insurance company. These activities make service users perceive that the efficient fulfilment of their needs and demands is the focus of all the activities of the insurance company. In this way, marketing communication creates positive impressions which increase the satisfaction of users and contribute to the development of long-term relations with them.

The factors such as intense competitiveness, fast development and the application of new information-communication technology, fragmentation of the media and changes in users' behaviours have influenced changes in the strategy of marketing communication. Contemporary business conditions determine the establishment of an interactive dialogue between the company and users and it occurs in all stages of the purchase process. In the pre-purchase stage, the role of marketing communication is to inform potential users, to make them interested and to create preferences towards the company's offer. By applying the adequate forms of marketing communication during the stage of using the service, the company tends to explain the stages of the process of servicing to users and to provide them with support in solving possible problems. In the post-purchase stage, the aim of marketing communication is to increase the positive experience of service users. The strategy of marketing communication should contribute to the creation of realistic expectations and the fulfilment of promises given to service users. The unrealistic and exaggerated promises given in the pre-purchase stage can increase the level of users' expectations. If the company is not able to fulfil the given promises during the process of servicing, service users will feel betrayed after the completion of the process of providing services and they will perceive a low level of service quality. All this can affect their decision to end cooperation with the company.

The aim of the paper is to show the connection between marketing communication and attracting, satisfying and retaining insurance service users. The paper should point 
out the role of marketing communication activities in the establishment, development and maintenance of long-term relations with insurance service users. The results of the empirical research, which are presented in the paper, are significant because they indicate that the insurance company can improve its business performance by implementing and investing into the activities of marketing communication. A better understanding of the role and the increased investment of insurance companies into the activities of marketing communication add to the fact that these types of research are becoming more important.

The paper consists of five parts. The first part presents a theoretical concept of marketing communication - the understanding of the role of marketing communication. The second part of the paper analyses the influence of marketing communication on attracting insurance service users. The third part analyses the role of marketing communication in achieving the satisfaction of insurance service users and retaining them. The fourth part of the paper refers to the research methodology, and the fifth part includes a discussion about the research results.

\section{MARKETING COMMUNICATION - THEORETICAL CONCEPT}

A well-defined and implemented strategy of marketing communication enables the achievement of excellent business results and recognition of the company on the market. Kotler \& Keller (2006, p.536) states that by using marketing communication companies tend to inform, persuade and remind the target segment of consumers of the company's offer. Marketing communications represent the "voice" of the company and its brands and are a means by which it can establish a dialogue and build relationships with and among consumers (Keller, 2009, p.141). The efficient communication between the company and the target audience assumes that it occurs in both directions (Stanković, et.al., 2014, p.15).

The fact that, in the contemporary conditions, consumers are exposed to a large number of marketing messages has created the need for companies to start viewing marketing communication as an interactive dialogue which occurs during the process of purchase.

In the pre-purchase stage, by employing marketing messages, potential users are given a promise about future satisfaction with the services. In this stage, the role of marketing communication is to inform, draw the attention of potential users and create the preferences towards the company's offer. The behaviour of potential service users, which is characteristic for this stage, represents focusing a significant amount of attention to the comparison of alternatives with the aim of minimising the level of perceived risk. In this sense, each form of marketing communication will have different credibility with decision-makers. When deciding about the choice of a service or a service company, potential users collect information from different sources. Besides a previous experience of the user with the given service or service company, promotional activities of service companies are a significant source of information. However, due to the specificity of services, those potential users who do not have that personal experience will tend to collect information through direct communication, primarily with friends, relatives and acquaintances, but also with the employees of the service company. Contrary to classic mass communication of the producers of consumer goods, the employees of service companies, who use a direct contact with service users, have a significant position as the carriers of external marketing communication (Senić, et. al., 2008).

A marketing message should be created by taking into account the specifics and demands of the target segment of users. In this way, during the stage of providing the service, 
the ratio of their cancellation of the service is minimised. The role of marketing communication during the stage of providing service is to introduce and explain to users the stages of the service process. However, during the service process, certain problems can occur. In those situations, marketing communication represents the key instrument for an efficient resolution of the problem, while the emphasis is on the role of the employees who establish direct communication with service users.

The sense of confirming or not confirming expectations and promises given to service users is characteristic for the post-purchase stage. In this stage, the role of marketing communication is to use an adequate approach and information in order to resolve potential misunderstandings with users or to strengthen their positive impressions.

Marketing communication is a mutual term for different types of planned messages used by a company - economic propaganda, sales improvement, direct marketing, personal selling, public relations, sponsorship (Duncan, 2005, p.7). Shimp states that marketing communication is an approach whose implementation is used by marketing managers in order to inform, persuade and remind users of the company's offer (Shimp, et.al., 2013). Informing and persuading users and brand differentiating, with the aim of forming their positive attitudes and completing the transaction, are basic functions of marketing communication (Stanković, et.al., 2014, p.16). By using the combination of instruments of the communication mix, marketing managers tend to achieve a maximum communication influence. The starting and the ending point in the development of the strategy of marketing communication is the consumer. The consumer does not differentiate between direct and indirect forms of marketing communication, but believes that those are all the ways of persuasion used by the company. The consumer finds it confusing and unconvincing if he/she is faced with a non-consistent message. Therefore, in order to efficiently achieve defined goals of marketing communication, it is important that the messages to the consumers are presented in an integrated and consistent manner (Avramović, 2008).

\section{MARKETING COMMUNiCATION AND ATtRACTION OF INSURANCE SERVICE USERS}

The main aim of marketing activities of service companies is attracting and retaining service users. The leading factor which affects attracting of new and retaining the existing service users is satisfaction. Veljković (2009, p.101) believes that satisfaction is the reaction of consumers to the evaluation of the perceived difference between previous expectations (or a specific standard of performance) and the actual performances. For Ljubojevic (1998), the concept of satisfaction is abstract, and it represents the function of perception (the probability of an event) and expectation (the evaluation of an event after the delivery of service) of the consumer.

The activities of marketing communication contribute to the attraction of service users. Potential service users form their expectations on the basis of marketing messages of service companies given through direct and indirect forms of marketing communication, and based on conversations with friends and relatives. They form their expectations during the pre-purchase stage, and the degree of achieved satisfaction is evaluated during the stage after the use of service. The expectations of users are, primarily, oriented towards the quality of service, the adjustment of the offer to their requests, desires and needs, the empathy of employees, and the fulfilment of promises given through marketing communication. 
The ability of the company to fulfil and overcome the expectations of service users creates certain advantages. First of all, service users who have achieved a certain level of satisfaction will transfer a positive message to potential users. Users are often included in the process of service provision and they transfer their positive or negative experiences through informal direct communication to other potential users. When a potential user needs to make a decision regarding the choice of a service company or a service, an important source of information will include friends, relatives, and acquaintances. Then, their positive or negative experiences, i.e. the achieved degree of satisfaction, becomes significant. After making a decision regarding the purchase of a certain service and establishing interaction with the service company, the user forms an experience as a result of comparing previous expectations and achieved gain. They will share their experiences (positive or negative) with friends, acquaintances, relatives or through social networks, which speeds up the transfer of information.

When it comes to services, the greatest significance goes to personal selling as a direct form of marketing communication. Its goal is to inform potential users about the company's offer, to stimulate interest and to encourage them to purchase. Although the marketing message which is presented by employees to potential users is created in advance, it can be changed and adjusted, depending on a specific situation. The ultimate goal is to succeed in selling.

The most significant segment of personal selling includes the employees who establish direct communication with the potential users. Personal selling is a very effective factor in establishing contact between salespersons and buyers in two directions. The customers can inquire and ask the salespersons face-to-face questions. At the same time, they can discuss and reach a clear understanding and make a proper buying decision (Yousif, 2016, p.130). The contribution of those employees is reflected in understanding needs, collecting information about specific requests, expressing empathy and creating the offer according to the needs and desires of potential users. The role of personal selling in the pre-purchase stage is not emphasised, because the potential user is still collecting necessary information. During the stage of using the service, the user needs additional information which he/she receives through direct communication with employees with the aim of achieving complete satisfaction (Vračar, 2005). Also, the employees who know the needs of users well enough can represent the channel for offering new services.

Development and the increasing application of modern technologies has significantly influenced the expressed growth of applying direct marketing in the service sector. Direct marketing is based on databases. It enables personalised and interactive communication, receiving an immediate response from the user in the form of purchasing or asking for further information, and the effects can be measured. Marketing messages are most often sent by email or SMS. The activities of direct marketing enable the identification of potential service users, but also the increased level of loyalty of the existing ones. By receiving a direct response from the users (by phone, mail, or e-mail), companies create a database of potential users. The increase in the level of loyalty is achieved by adjusting the offer created on the basis of data from the database about users' preferences or special interests.

When it comes to mass forms of marketing communication, economic propaganda is applied most often. It attempts to persuade potential customers to purchase or consume a product or service. It is designed in such a way that it creates and reinforces brand image and brand loyalty (Kumar, et.al., 2011, p.83). Its significance is expressed with attracting new users, i.e. during the pre-purchase stage. The goal is to inform potential users about 
the company's offer and to minimise the perceived risk. The purpose of economic propaganda is to influence potential users so that they could think about or react to a service or a company in a certain way (Senić, et.al., 2008). Taking into consideration the characteristics of services, primarily the fact that they are not material, the company can "materialise" services by sending adequate marketing messages through economic propaganda. In this way, the potential service users are given the opportunity to compare alternatives and decision-making regarding the purchase is easier.

Considering the fact that the service sector does not have a large number of mediators, the improvement of sales as a mass form of marketing communication is less significant in relation to the previously mentioned forms. However, the growth of competition and the sensitivity of users to additional services, have conditioned a larger application of the improvement of sales. The activities of sales improvement imply the use of discounts, gifts, coupons, and organization of prizewinning games. The application of means for the improvement of sales enables a short-term increase in the sales volume, encourages users to respond quickly and attracts users of competitive companies, thus increasing the database of its own users, and the accomplished effects are easily measured.

\section{MARKETING COMMUNiCATION, SATISFACTION AND RETAINING SERVICE USERS}

The key factor for accomplishing a long-term competitive advantage and success of a company on the market is the satisfaction of service users. The specificity of the service sector is the fact that it represents a significant source of dissatisfaction in users. The tendency of users who are not satisfied with a service or a service company is to make a decision to end their cooperation. Therefore, with the aim of keeping and developing long-term relations with the users, companies tend to provide them with complete satisfaction. That is why it is important to base the activities of the company on users' expectations and needs. The satisfaction of users depends on the quality of service and it is based on a specific transaction. Satisfied users perceive the company's offer as having quality, which increases the ratio of repeated purchases, the spread of positive information, and a higher level of loyalty and trust (Thaichon, et.al., 2013).

The significance of the quality of services is particularly expressed in the process of retaining the existing users. Traditionally, service quality has been explained as the gap between customer expectation about the service and perception of how the service has been performed (Kumar, 2017, p.160). The quality of service represents the key characteristic of the service offer because that is the dimension through which the user perceives the successfulness of a service company. In order for the company to provide a service of a satisfactory quality, it is necessary to include all employees and to have a good understanding of the needs, demands and desires of users. Besides the focus of the company on the creation of a quality offer, there also needs to have a system which will efficiently control the creation and delivery of an adequate quality service.

The users form their expectations on the basis of information from formal and informal sources. Although the influence of information from informal sources is expressed, the key significance belongs to marketing communication. Users' expectations should be realistic when it comes to the possibilities of the company to satisfy their needs. Unrealistic expectations of users can add to the increase in sales volume only short-term, but, longterm, they will result in their dissatisfaction and the end of cooperation. 
The satisfaction of users is most often evaluated on the basis of their experiences with the company's offer, but also on the basis of their overall experience with consumption which is the result of comparing expected and delivered values (Stanković, 2002). The measurement of satisfaction is a complex and hardly noticed variable which is the result of the subjective evaluation of service users. The aim of measuring the satisfaction of service users is to quantitatively express their subjective perceptions in an objective manner (Veljković, 2009, p.122). The essence of the measuring of satisfaction is reflected in identifying factors which affect the level of loyalty in users and a repeated purchase. The measuring of users' satisfaction enables the company to acquire information about the cause of satisfaction and which elements of the offer have the strongest effect on the increase in the level of satisfaction.

Retaining users refers to focusing the marketing activities on the existing database of users. The company which wants to retain existing users, besides the fact that it tends to satisfy their expectations, is also oriented towards motivating them to remain at the company's offer by increasing their satisfaction (Lovreta, et.al., 2010). By delivering the service with additional value, traditional relations between the company and the user becomes a partnership. A satisfied user will use the company's service again, he/she will recommend the company and its services to other potential users and they will have no reason to consider an offer from competitors. This means that satisfaction is the key factor for retaining users.

By creating an offer which is in accordance with the users' demands and needs, the service company tends to make potential users into first-time users, and then into users who repeat the purchase. However, the users who use the service for the first time, as well as those who repeat their purchase, can simultaneously use competitors' services. In that case, a well-defined and implemented strategy of marketing communication enables the achievement of their loyalty and the development of long-term relations. Personal selling and sales improvement are the forms of marketing communication which have the greatest influence on retaining users, but the activities of economic propaganda, whose aim is reminding about the company's offer, are also significant (Kotler, et.al., 2017).

Personal selling is directed towards monitoring users' reactions and the level of achieved satisfaction. The employees tend to collect information about users' satisfaction through direct communication, to retain them and to encourage them to spread positive information. Also, they contribute to the establishment of long-term relations which are based on the confirmation of promises given in the pre-purchase stage. The implementation of activities which are directed towards the achievement of users' satisfaction will have an influence on their decision to use the company's services in the future.

The role of economic propaganda in the post-purchase stage is crucial for overcoming users' potential doubts in the correctness of the decision (Stanković, et.al., 2014). In this stage, the message of the economic propaganda has the aim of confirming users' right choice and to encourage them to repeat their purchase. By reminding them of the company's offer and affirming positive attitudes which have been previously adopted by users, economic propaganda contributes to the increase in repeated purchases. Economic propaganda leads to the creation of loyal users who are less sensitive to competitors' prices and offers (Avramović, 2008). 


\section{RESEARCH METHODOLOGY}

\subsection{The conceptual research model of the significance of marketing communication for attracting and retaining insurance service users}

The subject of research of this paper is the analysis of the significance of marketing communication for attracting and retaining insurance service users. The subject of research has been concretised by defining the research framework as it is shown in Figure 1.

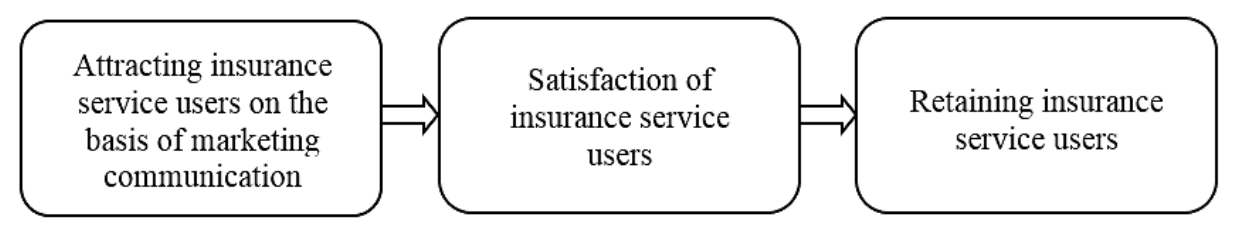

Fig. 1 The conceptual research model

Research questions for the definition of attracting insurance service users on the basis of marketing communication are:

1) What are the sources of information of insurance service users regarding the company's offer?

2) Do insurance service users notice the forms of marketing communication of insurance companies?

3) Do insurance service users notice marketing messages of insurance companies sent through the mass media?

4) Do insurance service users believe in marketing messages of insurance companies sent through the mass media?

5) Do insurance service users believe in marketing messages of insurance companies which they receive from a direct contact with the sellers of insurance services?

The research questions which refer to the satisfaction of insurance service users are:

6) How is the quality of the complete offer of the insurance company evaluated by insurance service users?

7) Are insurance service users satisfied with the services of the insurance company?

The research question for retaining insurance services users is:

8) What will be insurance service users' decision if the conditions of insurance are changed?

\subsection{The characteristics of the sample and the method of research}

In accordance with the defined subject and research questions, the research has been conducted by applying the research method. The structured questionnaire has been used as the main instrument for collecting primary data. The survey questionnaire mostly contains multiple choice questions, statements with which the respondents either agree or disagree, and the ranking of attitudes has been done by applying a Likert scale with scores from 1 to 5 .

The primary data are collected from the group which consists of 145 respondents, insurance service users. According to the gender of respondents, the numbers are almost equal, 74 women and 71 men. Out of the total number of respondents, the largest number of them are 46-55 years old (48), followed by the category of respondents who are 36-45 (38) 
and 26-35 (36), while the least represented include the categories of the youngest respondents who are 18-25 (4) and respondents who are over 60 years old (8). According to the level of education, the largest number of respondents has acquired higher education - a university degree (46), a master's degree (20) or a PhD (18), but the participation of respondents with a high-school degree (29) is also significant. Most respondents have their own sources of income. The largest number of respondents, 50 of them, state that they earn a monthly household income of 40,001-70,000 RSD, followed by the category of those who earn the income of 70,001-100,000 RSD (45).

\section{RESEARCH RESULTS AND DISCUSSION}

This part of the paper presents the research results and a discussion on the influence of marketing communication on attracting, satisfying and retaining insurance service users.

a) The analysis of attracting insurance service users.

The analysis of the answers of respondents to the first research question, regarding the sources of information while selecting the insurance company, shows that most insurance service users, 53 of them, have stated that they receive necessary information about insurance services through direct communication with the employees of the insurance companies, through personal selling. A significant source of information for insurance service users is also the informal communication with friends, relatives and acquaintances. Internet browsing and economic propaganda, as the mass form of marketing communication, are a less prevalent source on the basis of which users make a decision to establish cooperation with an insurance company. The research results are shown in Table 1.

Table 1 Sources of information of insurance service users

\begin{tabular}{lccc}
\hline Atitudes of insurance service users & $\mathrm{N}$ & $\begin{array}{c}\text { The number of users } \\
\text { who provided an answer }\end{array}$ & $\begin{array}{c}\text { \% users who } \\
\text { provided an answer }\end{array}$ \\
\hline Economic propaganda & 145 & 25 & 17,24 \\
Internet browsing & 145 & 16 & 11,03 \\
Talking to friends, relatives, acquaintances & 145 & 51 & 35,17 \\
Personal selling & 145 & 53 & 36,55 \\
\hline
\end{tabular}

Source: Authors' calculations

In the further course of the research, the respondents were supposed to state the forms of marketing communication of insurance companies which they have noticed. The answers of the respondents to the second research question - whether service users notice the forms of marketing communication of insurance companies - are shown in Table 2. The research results indicate that one insurance service user can notice more than one form of marketing communication. Table 2 also shows the respondents' answers to the third research question - whether service users notice marketing messages of insurance companies sent through the mass media. The largest percentage of respondents has noticed marketing messages sent through television, radio, newspapers, magazines and billboards $(44.25 \%)$. The percentage of noticed messages sent through the Internet (28.29\%), as well as the activities of personal selling (17.14\%), are also significant. The activities of sales improvement (discounts, prizewinning games, gifts) and direct marketing are noticed the least. 
Table 2 The percentage of noticed forms of marketing communication of insurance companies

\begin{tabular}{lccc}
\hline $\begin{array}{l}\text { The forms of marketing } \\
\text { communication }\end{array}$ & $\mathrm{N}$ & $\begin{array}{c}\text { The number of users who } \\
\text { provided an answer }\end{array}$ & $\begin{array}{c}\text { \% of users who } \\
\text { provided an answer }\end{array}$ \\
\hline Economic propaganda & 145 & 111 & 44.25 \\
Personal selling & 145 & 43 & 17.14 \\
Sales improvement & 145 & 14 & 5.58 \\
Direct marketing & 145 & 12 & 4.78 \\
Internet & 145 & 71 & 28.29 \\
\hline
\end{tabular}

The answers of the respondents to the fourth research question - whether insurance service users believe in the marketing messages of insurance companies sent through the mass media - are shown in Table 3. Although insurance service users have largely noticed the activities of economic propaganda of insurance companies, most of them either partially believe in or are indifferent towards the marketing messages sent through the mass media. The attitude of a relatively small number of respondents is, on the one hand, to completely believe in, or, on the other hand, not to believe at all in the activities of economic propaganda.

Table 3 The trust of insurance service users in the activities of economic propaganda of insurance companies

\begin{tabular}{lcccc}
\hline $\begin{array}{l}\text { The attitudes of insurance } \\
\text { services users }\end{array}$ & Mark & $\mathrm{N}$ & $\begin{array}{c}\text { The number of users who } \\
\text { provided an answer }\end{array}$ & $\begin{array}{c}\text { \% of users who } \\
\text { provided an answer }\end{array}$ \\
\hline I completely believe & 5 & 145 & 14 & 9.6 \\
I partially believe & 4 & 145 & 69 & 47.59 \\
I neither believe nor disbelieve & 3 & 145 & 36 & 24.83 \\
I slightly believe & 2 & 145 & 20 & 13.80 \\
I don't believe at all & 1 & 145 & 6 & 4.14 \\
\hline \multicolumn{4}{l}{ Source: Authors' calculations }
\end{tabular}

Unlike the indirect forms of marketing communication, the largest number of insurance service users, 93 of them, partially believe in the information they receive through communication with the sellers of insurance companies. The attitude of 26 respondents is that they completely believe in direct communication with the employees, 10 users slightly believe, while there are no users who do not believe at all. The respondents' attitudes regarding the fifth research question - whether insurance service users believe in the marketing messages which they receive from a direct contact with the employees - are shown in Table 4.

Table 4 The trust of insurance service users in the activities of personal selling of insurance companies

\begin{tabular}{lcccc}
\hline $\begin{array}{l}\text { The attitudes of insurance } \\
\text { service users }\end{array}$ & Mark & $\mathrm{N}$ & $\begin{array}{c}\text { The number of users } \\
\text { who provided an answer provided an answer }\end{array}$ \\
\hline I completely believe & 5 & 145 & 26 & 17.93 \\
I partially believe & 4 & 145 & 93 & 64.15 \\
I neither believe nor disbelieve & 3 & 145 & 16 & 11.00 \\
I slightly believe & 2 & 145 & 10 & 6.92 \\
I don't believe at all & 1 & 145 & 0 & 0 \\
\hline
\end{tabular}


b) The analysis of the level of achieved satisfaction of insurance service users.

The quality of the complete offer of an insurance company has been evaluated by the respondents with the application of a Likert scale, where 5 is the highest mark, and 1 is the lowest. The respondents' answers to the sixth research question - the evaluation of the quality of the complete offer of insurance companies - are shown in Table 5. The results of the research indicate that a significant number of insurance service users have evaluated the quality of the complete offer of insurance companies with high marks. There have been no lowest marks, while only one user has evaluated the quality of the offer with the mark 2.

Table 5 The evaluation of the quality of the complete offer of insurance companies

\begin{tabular}{ccccc}
\hline Mark & $\mathrm{N}$ & $\begin{array}{c}\text { The number of users who } \\
\text { provided an answer }\end{array}$ & $\begin{array}{c}\text { \% of users who } \\
\text { provided an answer }\end{array}$ & Mean value \\
\hline 5 & 145 & 70 & 48.28 & \\
4 & 145 & 62 & 42.76 & 4.39 \\
3 & 145 & 12 & 8.27 & \\
2 & 145 & 1 & 0.69 & 0 \\
1 & 145 & 0 & Source: Authors' calculations
\end{tabular}

In the further course of the research, the respondents were supposed to express their attitudes about the level of achieved satisfaction with insurance services. The respondents' answers to the seventh research question - whether insurance service users are satisfied with the services of insurance companies - are shown in Table 6. The attitude of most insurance service users is that they are very satisfied (58), or somewhat satisfied (63) with the services of insurance companies. The presented research results indicate that there are neither dissatisfied nor very dissatisfied users, while there are 24 users who are indifferent.

Table 6 The coefficient of the satisfaction of insurance service users

\begin{tabular}{lccccc}
\hline $\begin{array}{l}\text { The attitudes of insurance } \\
\text { service users }\end{array}$ & Mark & $\mathrm{N}$ & $\begin{array}{c}\text { The number of users who } \\
\text { provided an answer }\end{array}$ & Value & Mean value \\
\hline Very satisfied & 5 & 145 & 58 & 290 \\
Somewhat satisfied & 4 & 145 & 63 & 252 & 72 \\
Neither satisfied nor dissatisfied & 3 & 145 & 24 & 4.23 \\
Dissatisfied & 2 & 145 & 0 & \\
Very dissatisfied & 1 & 145 & Source: Authors' calculations
\end{tabular}

c) The analysis of retaining insurance service users

Depending on the level of achieved satisfaction and the fulfilment of promises given in the pre-purchase stage through marketing communication, insurance service users will make a decision regarding further cooperation with an insurance company. The respondents' answers to the eighth research question - what decision of insurance service users will be in case of changed conditions - are shown in Table 7. Retaining insurance service users has been measured as a percentage of users out of the whole sample who claim that they will use the services of the same insurance company. The attitude of the majority of insurance service users $(66.20 \%)$ is that, in case of changed conditions, they would think through 
before they make a decision. The decision to still use the services of the same insurance company, regardless of the changes of insurance conditions, will be made by $20.70 \%$ of users, while $13.10 \%$ of users will change their insurance company.

Table 7 The ratio of retaining insurance service users

\begin{tabular}{lcccc}
\hline The attitudes of insurance service users & Mark & $\mathrm{N}$ & $\begin{array}{c}\text { The number of users } \\
\text { who provided an answer provided an answer }\end{array}$ & $\begin{array}{c}\% \text { of users who } \\
\text { we }\end{array}$ \\
\hline $\begin{array}{l}\text { Still use the services of the same } \\
\text { insurance company }\end{array}$ & & 145 & 30 & 20.70 \\
Think through before making a decision & 2 & 145 & 96 & 66.20 \\
Change the insurance company & 1 & 145 & 19 & 13.10 \\
\hline
\end{tabular}

Source: Authors' calculations

\section{CONCLUSION}

The paper analysed the importance of marketing communication for the user in reaching a decision on using insurance services. The aim of the research was to determine the influence of marketing communication on attracting and retaining insurance beneficiaries.

The empirical research was conducted on the sample of 145 insurance beneficiaries. The results of the research showed that there is a positive correlation between marketing communication, and informing and creating the consciousness of potential users about the insurance company's offer. Also, the results indicated that there is a positive correlation between marketing communication and the user's decision to remain loyal to the insurance company. On the assumption that they have a choice, beneficiaries will remain loyal to the company as long as they are getting higher value in comparison with what they expect. This implies that a well-defined and implemented strategy of marketing communication considerably contributes to the attraction of new and retainment of current insurance beneficiaries. The realized research makes a significant contribution to the research of the role of marketing communication in establishing, developing and advancing longterm relations between beneficiaries and insurance companies.

The research has certain limitations. Above all, the results refer to the service sector, i.e. the insurance sector, and do not take into consideration details of all the organizations and sectors. Also, the research was carried out on the sample which cannot be considered representative. In accordance with the above-mentioned points, the authors believe that further research in this field is necessary in order to overcome the weaknesses.

\section{REFERENCES}

Avramović, M. (2008). Strategija privredne propaganda u sistemu integrisanih marketing komunikacija [Economic propaganda strategy in the system of integrated marketing communications]. Ph.D. Thesis. University in Niš.

Becić, S., Stojanović, M., \& Nikolić, M. (2018). Role of marketing and social networks in improving business effectiveness. Ekonomika, 64(3), 77-88.

Boateng, I., \& Aguey, S. (2020). Effect of Customer Satisfaction and Marketing Communication Mix on Customer's Loyality in the Ghanian Banking Industry. European Journal of Management and Marketing Studies, 5(4), 22-39. Retrived from: https://www.researchgate.net/publication/344151751_Issue_4_ 2020_EFFECT_OF_CUSTOMER_SATISFACTION_AND_MARKETING_COMMUNICATION_MIX_ ON_CUSTOMERS'_LOYALTY_IN_THE_GHANAIAN_BANKING_INDUSTRY Accessed on: November 01,2020 . 
Blaga, L. (2018). Integrated Marketing Communication and Its Impact on Consumer Behavior. Studies in Business and Economics, 13(2), 92-102. Retrived from: https://content.sciendo.com/view/journals/sbe/ 13/2/article-p92.xml?language=en Accessed on: November 01, 2020.

Ćurčić, N., Piljan, I., \& Simonović, Z. (2019). Marketing concept in insurance companies. Ekonomika, 65(3), 21-33.

Duncan, T. (2005). Principles of Advertising \& IMC. $2^{\text {nd }}$ edition. New York: McGraw-Hill, Irwin.

Kaftandjiev, Ch., \& Shustova, E. (2018). Fear Appeals in marketing Communications of Banks and Insurance Companies in the Continuum of Dramatic-Tragic Situations - The Semiotic Perspective. Faculty of Business Economics and Entrepreneurship, 1-2, 83-110. Retrived from: https://www.researchgate.net/ publication/331427975_Fear_appeals_in_marketing_communicatioof_banks_and_insurance_companies_in the_continuum_of_dramatictragic_situations_The_Semiotic_Perspective Acessed on: November 05, 2020.

Keller, K. (2009). Building strong brands in modern marketing communications environment. Journal of Marketing Communications, 15(2-3), 139-155.

Kotler, Ph., \& Keller, K. (2006). Marketing menadžment 12.izdanje [Marketing management $12^{\text {th }}$ edition]. Beograd: Data Status.

Kotler, Ph., \& Keller, K. (2017). Marketing menadžment 15.izdanje [Marketing management $15^{\text {th }}$ edition]. Beograd: Data Status.

Kumar, N., Noida, G., Gangal, D. V. K., \& Singh, K. (2011). Advertising and consumer buying behaviour: a study with special reference to Nestle Ltd. International Journal of Research in Commerce \& Management, 2(10), 83-87.

Kumar, A. (2017). Effect of service quality on customer loyalty and the mediating role of customer satisfaction: an empirical investigation for the telecom service industry. Journal of Management Research and Analysis, 4(4), 159-166.

Lovreta, S., Berman, B., Petković, G., Veljković, S., Crnković, J., \& Bogetić, Z. (2010). Menadžment odnosa sa kupcima [Customer relationship management]. Beograd: CID Ekonomski fakultet.

Ljubojević, Č. (1998). Menadžment i marketing usluga [Service management and marketing]. Novi Sad: Stylos.

Marinković, V., \& Senić, V. (2012). Analiza elemenata kvaliteta usluga u korporativnom bankarstvu [Analysis of service quality elements in corporate banking]. Ekonomski horizonti (januar-april 1), 13-22.

Rabasović, B. (2013). Očekivanja potrošača u turizmu [Consumer expectations in tourism]. Anali ekonomskog fakulteta u Subotici, (29), 93-104.

Robson, J. (2015). General insurance marketing: A review and future research agenda. Jornal of Financial Service Marketing, 20(4), 282-291. Retrived from: https://www.researchgate.net/publication/281972587_ General_insurance_marketing_A_review_and_future_research_agenda Accessed on: November 12, 2020.

Senić, R., \& Senić, V. (2008). Menadžment $i$ marketing usluga [Service management and marketing]. Kragujevac: Prizma.

Senić, R., \& Senić, V. (2013). Sprečavanje odlaska postojećih i pospešivanje povratka izgubljenih kupaca [Preventing the departure of existing and facilitating the return of lost customers]. Marketing, 44(4), 333-342.

Shimp, T., \& Andrews, C. (2013). Advertising, Promotion and other aspects of Integrated Marketing Communications, $9^{\text {th }}$ edition, South Western, Cengage Learning. Retrived from: https://fandango.home. xs4all.nl/Advertising\%20Promotion\%20and\%20Other\%20Aspects\%20of\%20Integrated\%20Mng\%20Com munications\%20\%20Terence\%20A.\%20Shimp\%20\&\%20J.\%20Craig\%20Andrews.pdf Accessed on: November 12, 2020.

Stanković, Lj. (2002). Međuzavisni marketing [Interdependent marketing]. Niš: Ekonomski fakultet.

Stanković, Lj. \& Đukić, S. (2014). Marketing komuniciranje [Marketing communication]. Niš: Ekonomski fakultet.

Stanković, J. (2018). Zeleni marketing i zeleni proizvod [Green marketing and green product]. Economics of Sustainable Development, 2(2). 37-46.

Thaichon, P., Quach, T.N. \& Lobo A. (2013). Marketing communications: Factors influencing brand loyalty of Internet service provider. Conference: Australian and New Zealand Marketing Academy Conference December 2013. Retrieved from: https://www.researchgate.net/publication/279970569_MARKETING_ COMMUNICATIONS_FACTORS_INFLUENCING_BRAND_LOYALTY_OF_INTERNET_SERVICE_ PROVIDERAccessed on: November 10, 2020

Veljković, S. (2009). Marketing usluga [Services Marketing]. Beograd: CID Ekonomski fakultet.

Vračar, D. (2005). Strategije tržišnog komuniciranja [Marketing communication strategies]. Beograd: CID Ekonomski fakultet.

Yousif, R. (2016). The Impact of Personal Selling on the Purchasing Behavior towards Clothes: A case Study on the Youth Category. International Journal of Marketing Studies, 8(5), 128-135.

Zeithaml, V. \& Bitner, M. (2003). Services Marketing, integrating customer focus acros the firm. International edition. New York: McGraw-Hill Higher Education. 


\section{ZNAČAJ MARKETING KOMUNICIRANJA ZA PRIVLAČENJE I ZADRŽAVANJE KORISNIKA USLUGA OSIGURANJA}

Pretopstavka uspeha procesa marketing komuniciranja u sektoru usluga je ostvarivanje dvosmerne interaktivne komunikacije između korisnika usluga i uslužnih organizacija.Uspešna strategija marketing komuniciranja usmerena je na privlačenje novih korisnika, ali $i$ na zadržavanje i izgradnju dugoročnih odnosa sa postojećim korisnicima usluga. Marketing poruka treba da bude kreirana u skladu sa definisanim ciljevima, karakteristikama i preferencijama ciljnog auditorijuma. Uloga marketing komunikacija je razlicita u zavisnosti od faze procesa kupovine. U fazi pre kupovine, cilj marketing komunikacija je da informišu potencijalne korisnike $i$ da kreiraju preferencije ka ponudi organizacije. U fazi korišćenja usluge, primenom adekvatnih oblika marketing komunikacija, organizacija nastoji da objasni i upozna korisnike sa procesom usluživanja i da pruži podršku prilikom rešavanja eventualnih problema. Potvrđivanje pozitivnih impresija korisnika i rešavanje eventualnih problema nastalih tokom procesa pružanja usluga, cilj je marketing komuniciranja u fazi posle kupovine.

Ključne reči: marketing komuniciranje, korisnik usluga, privlačenje, satisfakcija, zadržavanje korisnika usluga 